\title{
A ROMAN LEGIONARY IN CENTRAL ANATOLIA
}

\author{
M. Çetin ŞAHIN
}

During an archaeological survey in the territory of Haymana about 70 kilometers southwest of Ankara a professor of Hittitology, Hayri Ertem, found a number of epitaphs ${ }^{1}$. These epitaphs will be studied and published by one of my Greek students in a further issue of Archivum Anatolicum. Most of the inscriptions date from late Roman times. Below are three of these inscriptions, including a bilingual one erected by a Roman legionary for his parents. The readings are from the photographs:

1. Verissimus and Matrona. The relief-stele is located in the village of Büyükyağcı. Above, reliefs of three figures: in the middle that of the deceased, on the right that of his brother, on the left that of his wife. The inscription is within a tabula ansata. Late Roman. Plate I, 1 .

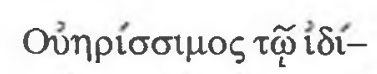

2 $\omega \alpha \operatorname{\alpha } \delta \varepsilon \lambda \varphi \widetilde{\omega} \kappa \alpha \grave{l} M \alpha \tau \rho \omega ́ v \alpha$

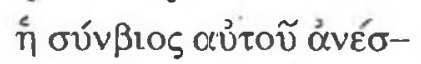

4

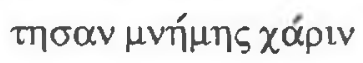

Translation: "Verissimus for his own brother, and Matrona, his wife (i.e. the wife of the deceased), erected (this stele) in his memory."

1-2 The name of the deceased is not indicated. It was probably written in paint beside his figure above. The names Verissimus and Matrona are both Roman. Matrona was in all probability not the wife of Verissimus, but of the deceased.

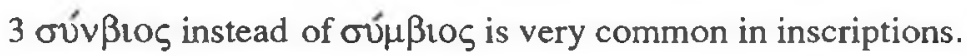

1. I should like to thank Professor Hayri Ertem for letting me know of these inscriptions and for the photographs. 
2. Sabinus, the priest of Christ. The inscription is in the village of Büyükyağcı. Early Christian. Plate I, 2.

\begin{tabular}{|c|c|}
\hline \multirow{3}{*}{\multicolumn{2}{|c|}{ Be⿱vos }} \\
\hline \multirow{4}{*}{2} & \\
\hline & \\
\hline \multirow{2}{*}{4} & \\
\hline \multirow{5}{*}{6} & \\
\hline & \\
\hline & \\
\hline & \\
\hline & \\
\hline & oิx $\chi^{\prime \prime \alpha p t \sigma \tau o \zeta ~}$ \\
\hline & 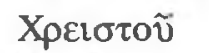 \\
\hline & 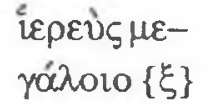 \\
\hline & 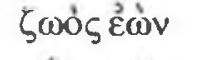 \\
\hline & 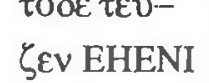 \\
\hline
\end{tabular}

Translation: "Sabinus, far the best priest of great Christ got this (tomb) prepared while alive".

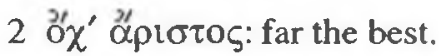

8-9 Probably a prohibition followed.

3. Gaius Iulius Aquila, soldier of legio XIII Didyme. The stele is on the wall of the small mosque (mescit) in the village of Balçıhisar. Ligature. Probably 2nd century A.D. Plate I, 3.

A

2 bene [ ]

B 「(óĩos)'Iov́dıs

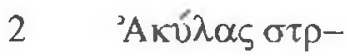
$\alpha \tau \imath$ ẃrnऽ $\Lambda \eta \gamma-$

$4 \tilde{\omega} \operatorname{vos} \tau \rho \varepsilon เ \sigma-$

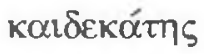

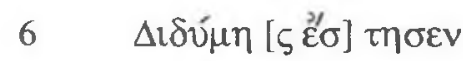

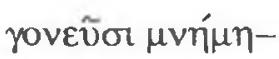
$8 \varsigma \chi \alpha \dot{\rho} \rho เ$ 
Translation: "Gaius Iulius Aquila, a soldier of legio XIII Didyme, erected (this tombstone) in the memory of his parents".

A 0-1 perhaps [...pa]/ren [tibus].

B 1-3 Gaius Iulius Aquila is a Roman name. Hence, it is possible that Gaius comes from Italy or from one of those provinces where Latin was spoken. The fact that the inscription is bilingual also points to the Latin descent of the soldier Gaius.

Hence, it is highly possible that his parents did not live in Asia Minor. The ashes of his parents may have been sent to him for burial in a cinerary urn. Another possibility is that Gaius, probably a veteran (see below), and his parents were living together in Asia Minor.

\section{3-4 $\lambda \eta \gamma \tilde{\omega} \vee \circ \zeta$ instead of $\lambda \varepsilon \gamma \varepsilon \tilde{\omega} \vee \circ \zeta$.}

3-6 The thirteenth legion had the cognomen Didyme, which was previously not known. Didyme was a place name in Armenia (see PapeBenseler, Griechische Eigennamen, s.v. $\left.\Delta 1 \delta u^{\prime} \mu \eta\right)$. Hence, it is very likely that legio XIII Didyme was attached to the province of Armenia. Hence, Gaius was probably a veteran living in central Anatolia.

For other Roman legionaries in central Anatolia, see for instance S. Mitchell, "Legio VII and the Garrison of Augustan Galatia", Classical Quarterly 26 (1976), pp.298-308; D. French, "Zeus Cicidiassenus", Festschrift für Sedat Alp, Ankara 1992, pp.193-196. 

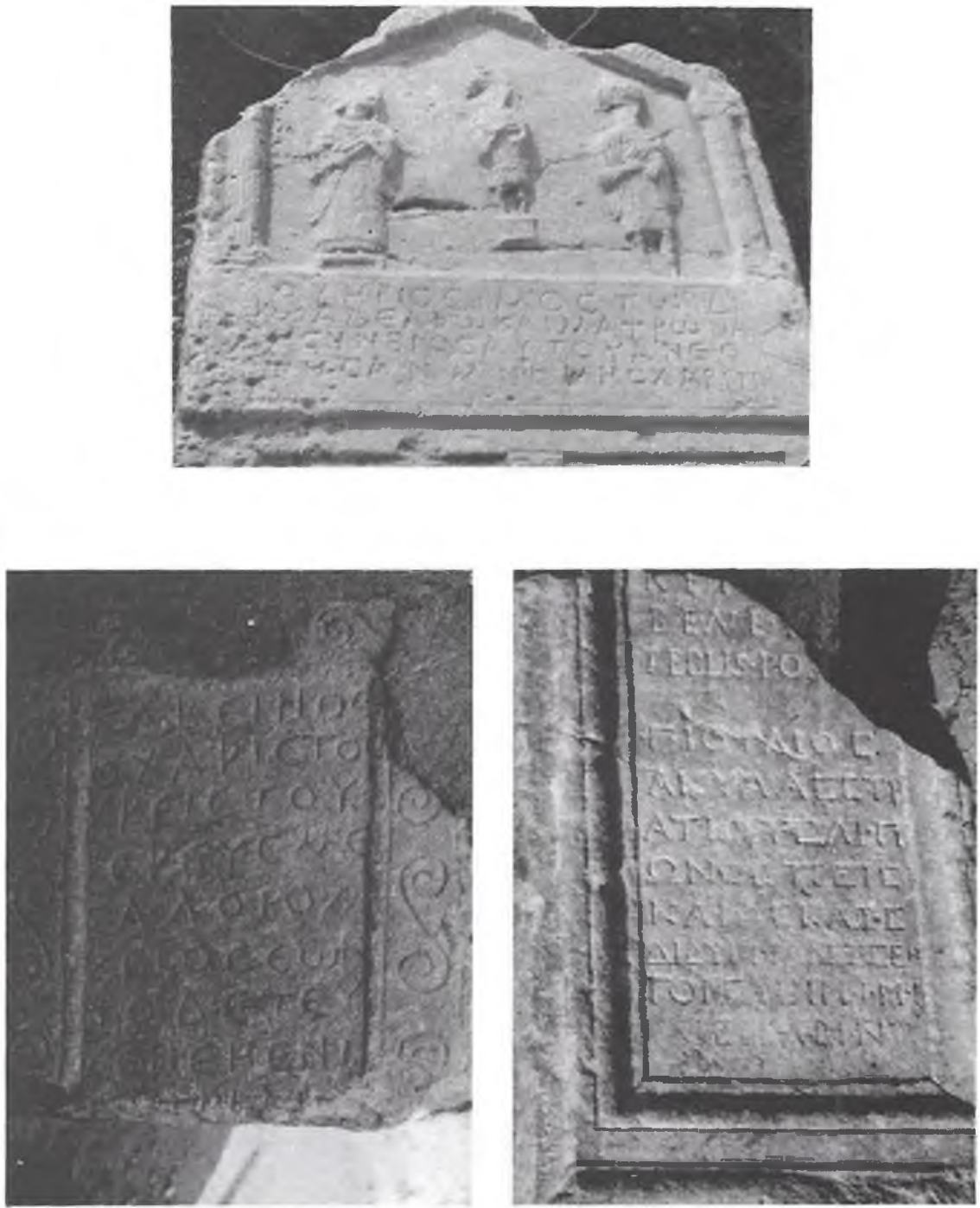